\title{
DETERMINATION OF DOLOG'S IDEAL WAREHOUSE BASED ON MINIMUM LOGISTICS COST
}

\author{
ERIANA ASTUTY \\ Faculty of Business and Management, Widyatama University \\ Jalan Cikutra 204 A, Bandung, Jawa Barat 40125 \\ E-mail: eriana.astuty@widyatama.ac.id
}

\begin{abstract}
ABSTRAK
Sebagian besar penduduk Indonesia mengkonsumsi beras sebagai makanan utama sehingga memerlukan jumlah beras yang mencukupi kebutuhan dalam waktu yang tak terbatas. Gudang penyimpanan diperlukan untuk mengelola persediaan beras.. Gudang beras harus berada di tempat yang strategis dan mudah dijangkau sehingga memperlancar pendistribusian dan menunjang efisiensi pendistribusian dalam segi ongkos logistik yang minimum. Dolog (Depot Logistik) merupakan agen tunggal Bulog (Badan Urusan Logistik) di Indonesia yang mempunyai tugas utama menjaga stabilitas dan ketersediaan bahan pangan di Indonesia terutama beras. Untuk dapat menjalankan tugasnya, Dolog harus mempunyai gudang beras ideal yang mempunyai kapasitas sesuai kebutuhan permintaan pasar. Penggunaan metode cluster dalam penelitian ini menghasilkan 3 gudang beras ideal dan strategis dalam memenuhi kebutuhan pasar di Bandung yang apabila dibandingkan dengan kondisi gudang sekarang yang sudah ada yaitu di Cimindi, ternyata dapat menghemat sebesar Rp 45.032.203 per tahun atau sekitar Rp125.000 per hari. Sehingga terdapat 2 solusi yang dapat diambil Dolog, yaitu membangun gudang beras baru di lokasi strategis atau tetap menggunakan gudang lama dengan menambah kapasitas gudang sebesar \pm 6.000 ton.
\end{abstract}

Kata kunci: dolog, gudang beras, metoda cluster, ongkos logistik

\begin{abstract}
Most of indonesian societies consume rice as staple food and therefore need the amount of rice that meet the demand within the infinite time. Food warehouse is needed in order to maintain supplies. Rice warehouse should be located in the strategic location so that it is easy to reach and to avoid the stagnation of supply. In addition, that can also be useful for financing streamline because it can minimize the logistics costs. Dolog as a unit of the agency Bulog is responsible to maintain the stability and availability of basic foodstuffs in the region of Indonesia and to participate in the procurement and supply of basic foodstuffs especially rice. To carry out its duties, Dolog also must have an ideal rice warehouse which its capacity should meet the demand of the rice according to the market supplied. The result of cluster method used in this research suggests that there are three ideal warehouse locations to supply main markets in Bandung. If the three ideal warehouse locations are compared with the existing warehouse, proposed warehouse location donates saving about IDR 45,032,203 per year or approximately IDR 125,000 per day. So there are two solutions can be taken by Dolog that the first is open new warehouses and the second is using the old warehouse and adding the shortage storage capacity by opening additional warehouse at $\pm 6,000$ tons.
\end{abstract}

Key words: dolog, rice warehouse, cluster method, logistics cost

\section{INTRODUCTION}

Along with the increasing demand for foodstuffs in this case, rice takes the current food supply. The current supply is supported by various factors, such as the smooth transportation of foodstuff, the efficient distance of foodstuff delivery, the intended location, the easy access of food sources location, and the most important is the availability of sufficient stock of food. In order to meet the sufficient stock of food, foodstuff storage facility is required. One of storage facilities to store food in large numbers is a warehouse. 
Warehouse of foodstuff as a temporary storage area where the production is accomodated within a certain time and taken out if market demand increases has a major function to prevent food shortages. Since rice is a kind of food that can not be produced each day, so rice warehouse has an important function. In the harvest season when the amount of rice is abundant, the majority of the stock of rice stored for distribution is back to the market during the period of waiting for the next harvest season, so the demand for rice will always be available.

Logistics agency known as Bulog is a nondepartmental agency that directly deals with issues related to Indonesian people's living. The sufficiency of food and nutrition which is evently distributed for all sections of population becomes a main focus to be developed by government. Equitable distribution of food and nutrition covers various dimensions such as place/location, volume and quality of population, and time. To support its work, Bulog is equipped with a set of Logistics Depot (DOLOG) in each province consisting of 88 sub Dologs in regency with 322 units of rice warehouse. There is forthcoming construction and currently on going construction of new warehouses spreading across Indonesia to remote the areas which is far from supply point, until then Bulog has warehouses with a total capacity of 2,000,000 tons throughout Indonesia.

Dolog (Logistics Depot) as a unit of the agency Bulog (National Logistics Agency) is responsible to maintain the stability and availability of the staple food in the area and to participate in the procurement and supply of basic foodstuffs, especially rice in each area. To carry out its duties, Dolog must have rice warehouses in ideal location and also its capacity should be sufficient for the demand of market supplied. By looking at the location of the existing market in Bandung city and the volume of rice needs in markets, Dolog can search for ideal location of warehouses that can provide rice stock in order to meet the needs. Searching for the ideal location can be done by using the grouping method (cluster method). This study determines the ideal location of warehouse in Bandung area with minimum logistics costs and compare the existing warehouse with the study to anticipate the needs of rice in the future.

\section{METHODS}

This is an applied research that intends to examine the application of a theory to solve the practical problems into a decision making. In this research, because the author has found several possible alternatives in terms of the strategic location among other locations so the cluster method is suitable to tackle alternatives group (Murti et al., 2004).

A fundamental problem in multiple facility location analysis is assigning customer demand to potential facility locations. Because there are so many possibilities for this assignment when there are many customers and many facility locations, making assignment in a logical and efficient fashion is useful (Ballou, 2003; Murti et al., 2004). In this method the market is grouped to obtain the location and number of optimal warehouse in order to get the balance of transportation cost with carrying cost so that the minimum total logistic cost is gained.

To solve the practical problems into decision making using the cluster method in this study, we should follow these steps below:

1. Determine the problem solving model, relevant variables, parameters, constraints, and requirement of problem solving.

2. Collect the data

Data is divided by internal data and external data

The internal data (from Bulog and Dolog) are:

- Rice demand;

- Cost of warehouse construction;

- Fixed cost;

- Transportation cost;

- Labor cost;

- Carrying cost

- The Cost of rice storage treatment.

The external data (from Government's Regulation, Badan Pusat Statistik which is known as Ststistics Indonesia, and another sources) are: 
- The location map, published by PT Djambatan;

- The transportation fee.

3. Calculation

- Determinating the location of customer (markets) into the grid.

- Calculating the forecasting demand using historical data.

- Estimating the transport rate and transportation cost equation.

- Calculating the depreciation.

- Estimating the carrying cost.

- The last step in this stpe is calculating the cluster method by constructing some iterations for seeking the minimum total cost as follows (Mulyati, 2011):

1. Begin with a warehouse at each demand or market site. Cost incurred in this solution includes maximum number of facilities.

2. Reduce the number of warehouses by grouping (clustering) two customers (a customer cluster) that are nearest each other into a new cluster and potential warehouse location.

3. Determine the location by using center of gravity theory (Thai and Grewal, 2005; Suthamphong, 2012) for the new customer group and assign a warehouse in this location.

4. Determine the total costs for this reduced number of locations.

5. Repeat steps 2 up to 4 until customer service considerations make further clustering disadvantageous, total cost increase, or only one location remains.

\section{RESULTS AND DISCUSSION}

\section{The Limitation of Problem}

The problem in this study is limited by several factors:

1. Research was conducted at Dolog Region III Bandung West Java.

2. Total market is accounted by market respondents representing the city of Bandung.

3. The inbound freight cost (of warehouse) is not taken into account.

4. All data and information are reliable and correct.
5. The distance from one point to another is equal to the inverse distance, and it is assumed that the distance on the map is flat, not valleys, rolling hills, or so forth.

6. Conditions have not changed during the study.

7. Fixed cost happening in the calculation is supposed to be constant and equal.

\section{Determination of Problem Solving Model, Variables, Parameters, Constraints, and Requirement of Problem Solving}

1. Problem solving model attempts to find the most appropriate warehouse location that has minimum total logistic costs. Total logistic costs $=$ transportation cost + carrying cost + fixed cost

2. Controlled and uncontrolled variables Controlled variables are variables that can be controlled by the company and usually these variables are internal. Included in these variables are:

- Location (grid) of 5 major markets in Bandung Municipality.

- Costs related to the transportation activities, such as labor cost, to transport rice from truck to warehouse per ton of rice (outslag), freight from warehouse to truck per ton of rice (uitslag), and freight/ton $/ \mathrm{m}$ from warehouse to market (outbound).

- Fixed costs.

- Costs incurred due to the storage of rice.

- Cost of warehouse construction according to the capacity.

Uncontrolled variables are variables that cannot be controlled by the company and usually these variables are external.

- Rice demand in each market for past several years, data taken from Dolog at rice procurement department.

- Land transport rates issued by Jabar Dolog.

- Natural disasters, including floods, very long droughts, volcanic eruptions, and others, cause the production of rice to decrease while the supply of rice is increasing.

- Politics, etc.

3. Parameters

Parameter is something that influences the system, which is generally outside the system 
itself, and considered to have a fixed price within a specified time. example:

- The price of fuel per liter that affects on the determination of the cost of transport/ land freight rates issued by Dolog Jabar.

- The cost of electricity per KWh units that influences the determination of fixed costs.

- Price of water (taps) per unit $\mathrm{m}^{3}$ which influences the determination of fixed costs.

- The price of medicines used in treatment process of storage in warehouse.

4. Determination of constraint used in problem solving

The constraints used in problem solving consist of:

- The observation area in terms of rice consumers is Bandung Municipality.

- Funds are provided according to the large volume of warehouse capacity/unit, that are:

- One (1) unit of a warehouse with a capacity of 1,000 tons, the construction cost is IDR 110,595,000.

- One (1) unit of a warehouse with a capacity of 2,000 tons, the construction cost is IDR 180,050.000.

- One (1) unit of a warehouse with a capacity of 3,500 tons, the construction costs IDR 330,572,500.

- Economic life of a warehouse building is 25 years old.

5. Determination of requirement for problem solving

The requirements imposed in the determination of problem solving are as follows:

- Each requirement/demand of rice must be met.

- Warehouse location must be strategic for every consumer.
- Logistics costs of selected warehouse must be minimum.

\section{Data Collection}

The data is taken based on the real information and estimation. The obtained data generally consist of data that can be used directly in the analysis and the data that needs to be processed first so that it can be used in the analysis.

The required data are:

1. Location map of 5 major markets in Bandung Municipality

The map of Bandung region used in this study refers to the map published by PT Djambatan with 1: 60,000 scale (in units of $\mathrm{cm}$ ). On the map, grid coordinates is done (the grid) in order to facilitate the calculations matemathically. With this coordinate system, the location of 5 major markets in Bandung municipality can be expressed in terms of the coordinates which is shown in the following Table 1:

2. Rice demand

The data of rice demand of 5 major markets in Bandung municipality are obtained from rice retail sales volume that is monitored by the BPS Bandung in collaboration with Dolog of West Java.

Table 1. Location Coordinate of 5 Major Markets in Bandung Municipality

\begin{tabular}{llcc}
\hline No & $\begin{array}{c}\text { Names of } \\
\text { Markets }\end{array}$ & $\begin{array}{c}\text { Coordinate } \\
\text { X }\end{array}$ & $\begin{array}{c}\text { Coordinate } \\
\text { Y }\end{array}$ \\
\hline 1 & Caringin & 5 & 4 \\
2 & Ciroyom & 6.2 & 8.5 \\
3 & Baru & 8.2 & 8.5 \\
4 & Kosambi & 11.3 & 8.5 \\
5 & Sederhana & 8 & 13 \\
\hline
\end{tabular}

(Source: Peta PT Djambatan)

Table 2. Rice Demands

\begin{tabular}{lcccccc}
\hline \multirow{2}{*}{ MARKET } & \multicolumn{7}{c}{ Total Demand (tons) } \\
\cline { 2 - 7 } & $\mathbf{2 0 0 0}$ & $\mathbf{2 0 0 1}$ & $\mathbf{2 0 0 2}$ & $\mathbf{2 0 0 3}$ & $\mathbf{2 0 0 4}$ & $\mathbf{2 0 0 5}$ \\
\hline Caringin & $7,617.03$ & $7,899.24$ & $7,222.08$ & $8,263.83$ & $7,874.29$ & $8,068.00$ \\
Ciroyom & $4,499.60$ & $4,666.31$ & $4,266.29$ & $4,881.68$ & $4,651.57$ & $4,766.00$ \\
Baru & $3,719.77$ & $3,857.59$ & $3,526.90$ & $4,053.63$ & $3,845.40$ & $3,940.00$ \\
Kosambi & $5,214.84$ & $5,482.15$ & $4,840.75$ & $5,827.49$ & $5,458.52$ & $5,642.00$ \\
Sederhana & $9,310.75$ & $9,655.71$ & $8,827.98$ & $10,101.4$ & $9,625.22$ & $9,862.00$ \\
\hline
\end{tabular}

(Source: Bulog 1994, West Java \& BPS 2008, West Java) 
If the distribution of demand above is plotted into the graph, it would seem that the demand of rice in each market will tend to be a rising trend and the data distribution fluctuates. This is caused by the demand of rice increases in accordance with the increase of population rate.

3. Cost of warehouse construction for different warehouse capacity

The cost of warehouse construction include the following:

- The cost of land acquisition.

- Lisencing.

- The cost of warehouse construction, etc.

In this study, the data used as the cost of warehouse construction are derived from Dolog in West Java as shown in the Table 3.

4. Fixed costs per year

The fixed costs consist of components such as warehouse facility maintenance, warehouse equipment maintenance, fuel for warehouse operations, warehouse management, electricity and water, and warehouse operations. These costs can be considered as fixed cost because the cost per year is almost the same (not depending on the volume of stored rice). The cost of warehouse operations in this case means costs allocated for warehouse personnel such as chief of warehouse, security, and others. The data is shown in Table 4 are obtained from Dolog of West Java, the irregularities or oddity on the magnitude of the cost exists because the data taken refer to the situation that occurred in the field a few years ago (before the decline

Table 3. The Cost of Warehouse Construction

\begin{tabular}{lll}
\hline No & \multicolumn{1}{c}{ Components } & Total Cost (IDR) \\
\hline 1 & $\begin{array}{l}1 \text { unit of warehouse } \\
\text { capacity of } 1,000\end{array}$ & $110,595,000$ \\
& tons \\
2 & $\begin{array}{l}1 \text { unit of warehouse } \\
\text { capacity of } 2,000\end{array}$ & $180,050,000$ \\
& $\begin{array}{l}\text { tons } \\
1 \text { unit of warehouse } \\
\text { capacity of 3,500 } \\
\text { tons }\end{array}$ & \\
\hline
\end{tabular}

(Source: Bulog 1994, West Java)
Table 4. Fixed Cost per Year

\begin{tabular}{llr}
\hline No & \multicolumn{1}{c}{ Components } & Cost (IDR/year) \\
\hline 1 & Warehouse phyisical & $1,200,000.00$ \\
& $\begin{array}{l}\text { care } \\
2\end{array}$ & $\begin{array}{l}\text { Warehouse equip. } \\
\text { maintenance }\end{array}$ \\
\multirow{2}{*}{3} & Fuel of warehouse & $600,000.00$ \\
& operation & $330,000.00$ \\
4 & Warehouse mgt. & $420,000.00$ \\
5 & Electricity and water & $6,848,400.00$ \\
6 & Warehouse operation & $10,837,200.00$ \\
\hline
\end{tabular}

(Source: Bulog 1994, West Java)

in value of Rupiah), and further this research considers that the conditions in the field have not changed so that all data and information are considered correct.

5. Overland freight rates and transportation costs

The transportation costs are related to:

- The labor cost to transport rice from truck to warehouse (outslag).

- The labor cost to transport rice from warehouse to truck (uitslag).

- Freight from warehouse to the market (outbound).

Dolog sets IDR 1,500/ton (each fare is IDR 750 per ton) for outslag and uitslag costs. While the rate of land transport, particularly for transportation in the city (municipality of Bandung), Dolog sets tariff of IDR 7,652 per $10 \mathrm{kms}$. If we look the magnitude of the wage given to workers to transport 1 ton of rice from truck to warehouse and vice versa, it counts only IDR 1,500/ton (wages only to transport the rice, it does not mean monthly salary).

6. Costs incurred for rice storage

Carrying cost comes up as the activities of goods storage. When carrying cost is high, inventory is made as small as possible and vice versa if the carrying cost is low, the inventory may be stacked in large quantities depending on the condition of the goods stored and other cost factors. Likewise rice in Dolog storage, carrying costs that occured in the field is only issued to cover depreciation cost of the warehouse (space cost) and the treatment for 
rice stored (inventory risk cost). The treatment is done by cleaning of germs (disinfection), as for the way of fumigation (fogging) and spraying. The amount of the carrying cost in Dolog of West Java is influenced by the following things:

Building depreciation costs are determined by considering:

- The magnitude of the warehouse capacity.

- Funds/costs of warehouse construction.

- The expected residual value.

- Economic life of building (warehouse).

The cost of rice storage treatment (inventory risk cost):

- Spraying counts for IDR 250 per ton.

\section{Data Processing}

\section{Determination of the Number and the} Location of Customers

The number of costumers in this case is market, include five markets. The location can be determined by looking at the map and grid coordinates. On the base map in $1: 60,000$ scale (cm), it is conducted by making the grid coordinates (mesh nets) to facilitate mathematical calculations. With the grid coordinates, the location of the market and the location of the warehouse can be expressed in terms of the coordinates so it can be compiled in mathematical form.

\section{Determination of the Amount of Demand in Each Market}

In this study, the amount of demand of each market is determined based on data forecast. The forecasting methods suggested are double moving average, double exponential smoothing, and linear regression methods. Selection of the three kinds of statistical forecasting methods is adapted to the shape/pattern of historical demand data and the result shows that the pattern seems to be rising trend and data distribution is fluctuating. Furthermore, the most suitable method is chosen according to the one which contains the smallest error value of the Mean Square Error (MSE).

The best forecasting method based on MSE is linear regression method because this method
Table 5. The Data of The Forecasting Result

\begin{tabular}{clc}
\hline No & $\begin{array}{r}\text { Name of } \\
\text { Markets }\end{array}$ & $\begin{array}{r}\text { Forecasting Result } \\
\text { in 2008 (ton/yr) }\end{array}$ \\
\hline 1 & Caringin & $8,330.35$ \\
2 & Ciroyom & $4,920.98$ \\
3 & Baru & $4,068.12$ \\
4 & Kosambi & $5,890.50$ \\
5 & Sederhana & $10,182.69$ \\
\hline Total & & $33,392.64$ \\
\hline
\end{tabular}

produces the smallest error values among two other methods. In this study, forecast demand rely on the result of forecast demand in 2008. Demand in 2008 are the largest data due to the forecast results of the next three periods. The selection of largest data is intended to anticipate fluctuations. The largest forecasted demand in 2008 is used as the current demand of each market to calculate the cost of logistics which is done using cluster method.

Based on early explanation of the total logistics costs, it is defined as sum of transportation cost, carrying costs, and fixed costs. So it seems clear that before solving the model of problem, the cost component and its estimation must be determined in advance. The formula to estimate the transportation cost and the carrying cost does not follow a certain formula because the input parameter of cost relies on the case of real life. The data obtained directly from the field is analyzed and then used to calculate total ligistics cost according to the formula defined previousely.

\section{Estimating the Transport Rate and Transportation Cost}

The formula of transport rate is constructed based on the data and the conditions that occured in the field related to the transportation problem. This transport rate formula will be used to search for transportation cost where the formula of transportation cost is the multiplication of transport rate and volume. By looking at the conditions in the field and the data collected, finally transport rate equation can be estimated as follows: 
Transport Rate $=$ Freight Workers $+($ Cost of Freight Transport $\times$ Distance) ....(1)

Freight workers are divided into 2 categories: from truck to warehouse (outslag) of IDR 750/ton and from warehouse to truck (uitslag) of IDR $250 /$ ton. While the rate of overland transport, particularly for transport in the city (municipality of Bandung), Dolog sets tariff of IDR 7,652 per $10 \mathrm{~km}$. Transport distance unit is measured in meters, so the transport rate formula becomes= Outslag \& Uitslag Cost + (Cost/ton $/ \mathrm{m} \times$ Distance).

Transport Rate $=1,500+(0,7652 \times$ Distance $)$. By applying the equation transport rate, then transportation cost will follow the formula:

Transportation Cost $=$ Transport Rate $\times$ Volume

\section{Estimating The Carrying Cost (CC)}

For carrying cost, the estimation process is done by looking at the condition which actually happened in the field related to the problem of storage in the warehouse and also looking at the data pattern of carrying cost for the last few years based on demand. Based on the data pattern of carrying cost, it implies that between the inventory risk cost and the number of stored volume approximates the shape of the graph root. And the data obtained can finally be used to estimated the carrying costs in Dolog through this following formula:

$\mathrm{CC}=$ Dep. $+($ Inventory Risk Cost $\times(\sqrt{\text { volume }}))$

$\mathrm{CC}=$ Dep. $+(1,000 \times(\sqrt{\text { volume }}))$

(4)

Where:

Dep.: depreciation of the value of the warehouse Inventory risk cost is the sum of the fumigation of IDR 750/ton + spraying of IDR 250/ton = IDR $1,000 /$ ton

Volume: the amount of carrying demand

\section{Depreciation Calculation Process}

Depreciation is required in order to estimate the carrying cost, where the carrying cost is one of the determinants of logistics costs to be calculated. Depreciation is computed using the straight-line method (straight line), taking into account economic life of the building (warehouse) for 25 years and a residual value of $10 \%$.

\section{The Calculating of Logistics Cost through the Clustering Process}

\section{Cluster 0}

1. Assume that the location of rice warehouse is located in each market. By admitting this assumption in step, the cluster method is called with cluster 0 .

2. Calculate logistics costs in the cluster above (cluster 0).

3. Reduce the number of warehouse one by one by grouping two markets which are closest to each other into a new group with a potential warehouse (to serve the two grouped market). While the location of the warehouse in other markets remains on the initial assumption (warehouse located in each market). The cluster index is defined as follows: after cluster (t) is done, then the next cluster is called cluster $(t+1)$. So after cluster 0 , the next cluster is the cluster 1 .

\section{Cluster 1}

\section{Between Ciroyom and Baru}

The new warehouse location for the two grouped markets could be found by using the center of gravity (Thai and Grewal, 2005; Suthamphong, 2012).

$$
\begin{aligned}
& X=\frac{\left(X_{1} \cdot d_{1}\right)+\left(X_{2} \cdot d_{2}\right)}{d_{1}+d_{2}} . \\
& Y=\frac{\left(Y_{1} \cdot d_{1}\right)+\left(Y_{2} \cdot d_{2}\right)}{d_{1}+d_{2}} .
\end{aligned}
$$

Where:

$\mathrm{X}, \mathrm{Y}=$ Center of Gravity from two locations

$\mathrm{X}_{1} \quad=$ The Axis of location 1

$\mathrm{X}_{2} \quad=$ The Axis of location 2

$\mathrm{Y}_{1}=$ The ordinat of location 1

$\mathrm{Y}_{2}=$ The ordinat of location 2

$\mathrm{d}_{1}=$ Demand on location 1

$\mathrm{d}_{2} \quad=$ Demand on location 2

So the center of gravity form Ciroyom and Baru using the formula (5) and (6) is: 


$$
\begin{aligned}
& \mathrm{X}=\frac{(4,069.12 \times 8.2)+(4,920.98 \times 6.2)}{(4,068.12+4,920.98)}=7.11 \\
& \mathrm{Y}=\frac{(4,068.12 \times 8.5)+(4,920.98 \times}{(4,068.12+4,920.98)}=8.50 \\
& (\mathrm{X}, \mathrm{Y})=(7.11,8.50) \rightarrow \text { Center of Gravity Cluster } \\
& 1(\mathrm{Cg} 1)
\end{aligned}
$$

- It should be noted that for the three other markets are not grouped, it is assumed that the location of the warehouses are located in each market (as in cluster 0 ). So all calculations regarding the logistics costs are same as the cluster 0 .

- The total cost of logistics in cluster 1 is the total cost of logistics in five markets, as listed in Table 7, IDR213,400,701.87/yr.

- Because the total logistics cost in cluster 1 is smaller than the total logistics cost in cluster 0 , this leads to a new warehouse layout for Baru and Ciroyom are in Cg_1 (warehouse location for the three other markets remain on the initial assumptions) and the clustering process will be forwarded to cluster 2 (repeat the clustering process as the process no. 3), by grouping warehouses in $\mathrm{Cg}_{-} 1$ with the next closet markets (the location of the warehouse to the other two markets remains in the initial assumption).

- If the results of the new cluster give total logistics costs less than existing total logistics cost, so continue the process of clustering with another new warehouse by combining the result of new clustered warehouse with the next adjacent market. The iteration of clustering process should be stopped if the total logistics costs gives

\begin{tabular}{|c|c|c|c|c|c|c|c|}
\hline \multirow[b]{2}{*}{ Wrhs } & \multirow[b]{2}{*}{ Mrkt } & \multirow[b]{2}{*}{$\begin{array}{l}\text { Dstnce } \\
\text { (m) }\end{array}$} & \multicolumn{2}{|c|}{ Transport } & \multirow[b]{2}{*}{ CC (IDR) } & \multirow[b]{2}{*}{$\begin{array}{l}\text { Fixed cost } \\
\text { (IDR) }\end{array}$} & \multirow[b]{2}{*}{$\begin{array}{l}\text { Total cost } \\
\text { (IDR) }\end{array}$} \\
\hline & & & $\begin{array}{c}\text { Rate } \\
\text { (IDR/ton) }\end{array}$ & Cost (IDR) & & & \\
\hline Cg_1 & Baru & 656.93 & $2,002.68$ & $8,147,135.18$ & $13,747,830.19$ & $9,185,003.19$ & $31,082,628.69$ \\
\hline $\mathrm{Cg} \_1$ & Crym & 543.07 & $1,915.56$ & $9,426,427.90$ & $16,630,000.12$ & $11,110,596.81$ & $37,169,483.47$ \\
\hline Kos & Kos & 0 & 0 & 0 & $19,522,149.61$ & $20,295,600.00$ & $39,817,749.61$ \\
\hline Crgn & Crgn & 0 & 0 & 0 & $28,936,900.77$ & $20,295,600.00$ & $49,232,500.77$ \\
\hline \multirow[t]{2}{*}{ Sdrh } & Sdrh & 0 & 0 & 0 & $35,802,739.33$ & $20,295,600.00$ & $56,098,339.33$ \\
\hline & & & & & & \multicolumn{2}{|c|}{ Total Cost: $213,400,701.87$} \\
\hline
\end{tabular}
greater value than the total logistics costs in the previous cluster, and so on.

\section{Cluster 2}

\begin{tabular}{|c|c|c|c|c|c|c|c|}
\hline \multirow[b]{2}{*}{ Wrhs } & \multirow[b]{2}{*}{ Mrkt } & \multirow[b]{2}{*}{$\begin{array}{c}\text { Dstnce } \\
\text { (m) }\end{array}$} & \multicolumn{2}{|c|}{ Transport } & \multirow[b]{2}{*}{ CC (IDR) } & \multirow{2}{*}{$\begin{array}{l}\text { Fixed cost } \\
\quad \text { (IDR) }\end{array}$} & \multirow{2}{*}{$\begin{array}{l}\text { Total cost } \\
\text { (IDR) }\end{array}$} \\
\hline & & & $\begin{array}{c}\text { Rate } \\
\text { (IDR/ton) }\end{array}$ & Cost (IDR) & & & \\
\hline $\mathrm{Cg} 22$ & Baru & 339.47 & $1,759.76$ & $7,158,914.95$ & $14,136,496.15$ & $5,548,863.7$ & $2,684,637.00$ \\
\hline Cg_2 & Crym & $1,539.47$ & $2,678.00$ & $13,178,387.26$ & $17,100,146.85$ & $6,715,157.4$ & $36,994,908.97$ \\
\hline Cg_2 & Kos & $1,520.53$ & $2,663.51$ & $15,689,416.22$ & $20,469,198.96$ & $8,034,579.0$ & $44,197,378.16$ \\
\hline Crgn & Crgn & 0 & 0 & 0 & $28,936,900.77$ & $20,295,600.0$ & $49,232,500.77$ \\
\hline Sdrh & Sdrh & 0 & 0 & 0 & $35,802,739.33$ & $20,295,600.0$ & $56,098,339.33$ \\
\hline
\end{tabular}

Table 7. The Results of The Cluster 1 (Cg_1 (7.11;8.50))

$($ Cg_1 = Center of Gravity Cluster 1, Crym = Ciroyom, Kos = Kosambi, Crgn = Caringin Sdrh = Sederhana $)$

Table 8. The Results of Cluster $2\left(\mathrm{Cg}_{-} 2(8.77 ; 8.50)\right)$

Total cost: $213,369,501.24$

$\left(\mathrm{Cg} \_1=\right.$ Center of Gravity Cluster $1, \mathrm{Cg} \_2=$ Center of Gravity Cluster 2, Crym = Ciroyom, Kos $=$ Kosambi, Crgn $=$ Caringin Sdrh $=$ Sederhana) 


\section{Between $\mathrm{Cg} 1$ and Kosambi}

It is evident that the logistics costs in cluster 2 is smaller than the cluster 1 so it can be said that the clustering process is proper and warehouse location for the third market (Ciroyom, Baru, and Kosambi) is appropriately located at the axes point of Cg_2 (8.77; 8:50). Further clustering process is proceeded to the next nearest market.

Cluster 3

Iteration 1: between $\mathrm{Cg} \_2$ and Caringin

When looking at the cluster 3 iteration 1 , logistics costs turned out to be greater than the previous cluster (cluster 2), therefore, that cluster is considered to be improper and cannot be forwarded. Therefore cluster 3 should be regrouped by trying to classify $\mathrm{Cg}$ _ 2 with other nearby markets (besides Caringin, because it obviously cannot be grouped).
Cluster 3

Iteration 2: Between $\mathrm{Cg} \_2$ and Sederhana

Cluster 3 Iteration 2, also results a greater logistic costs rather than cluster 2 so this implies that between $\mathrm{Cg}_{-} 2$ and other markets is not

Table 11. The Result Of Whole Clustering Process

\begin{tabular}{llc}
\hline No & Clustering Process & $\begin{array}{c}\text { Total Logistics } \\
\text { Costs (IDR) }\end{array}$ \\
\hline 1 & $\begin{array}{c}\text { Cluster 0 (warehouse } \\
\text { on each market } \\
\text { amounted 5 ) }\end{array}$ & $218,700,771.18$ \\
2 & $\begin{array}{c}\text { Cluster 1 (warehouses } \\
\text { totaling 4) }\end{array}$ & $213,400,701.87$ \\
3 & $\begin{array}{c}\text { Cluster 2 (warehouse } \\
\text { totaling 3) }\end{array}$ & $213,369,501.87$ \\
4 & $\begin{array}{c}\text { Cluster 3 Iteration 1 } \\
\text { (failed) }\end{array}$ & $224,016,025.49$ \\
5 & $\begin{array}{c}\text { Cluster 3 Iteration 2 } \\
\text { (failed) }\end{array}$ & $226,405,826.38$ \\
\hline
\end{tabular}

Table 9. The Results of The Cluster 3 Iteration 1 (Cg_3 (7.41;6.88))

\begin{tabular}{|c|c|c|c|c|c|c|c|}
\hline \multirow[b]{2}{*}{ Wrhs } & \multirow[b]{2}{*}{ Mrkt } & \multirow{2}{*}{$\begin{array}{c}\text { Dstnce } \\
\text { (m) }\end{array}$} & \multicolumn{2}{|c|}{ Transport } & \multirow[b]{2}{*}{ CC (IDR) } & \multirow{2}{*}{$\begin{array}{l}\text { Fixed cost } \\
\quad \text { (IDR) }\end{array}$} & \multirow{2}{*}{$\begin{array}{l}\text { Total cost } \\
\text { (IDR) }\end{array}$} \\
\hline & & & $\begin{array}{c}\text { Rate } \\
\text { (IDR/ton) }\end{array}$ & Cost (IDR) & & & \\
\hline Cg_3 & Baru & $1,212.36$ & $2,427.70$ & $11,946,657.41$ & $16,770,973.02$ & $4,303,076.75$ & $33,024,347.24$ \\
\hline Cg_3 & Crym & $1,077.68$ & $2,324.64$ & $9,456,893.99$ & $13,864,378.77$ & $3,557,304.20$ & $26,881,979.36$ \\
\hline Cg_3 & Kos & $2,524.86$ & $3,432.02$ & $20,216,329.60$ & $20,075,150.76$ & $5,150,864.01$ & $45,448,301.24$ \\
\hline Cg_3 & Crgn & $2,257.06$ & $3,227.10$ & $26,882,923.47$ & $28,390,295.72$ & $7,284,354.95$ & $62,563,058.31$ \\
\hline Sdrh & Sdrh & 0 & 0 & 0 & $35,802,739.33$ & $20,295,600.00$ & $56,098,339.33$ \\
\hline
\end{tabular}

$\left(\mathrm{Cg} \_1\right.$ = Center of Gravity Cluster 1, Cg_2 = Center of Gravity Cluster 2, Cg_3 = Center of Gravity Cluster 3 Iteration 1 , Crym $=$ Ciroyom, Kos $=$ Kosambi, Crgn $=$ Caringin Sdrh $=$ Sederhana)

Table 10. The Results of The Cluster 3 Iteration $2\left(\mathrm{Cg}_{-} 3(8.45 ; 10.33)\right)$

\begin{tabular}{|c|c|c|c|c|c|c|c|}
\hline \multirow[b]{2}{*}{ Wrhs } & \multirow[b]{2}{*}{ Mrkt } & \multirow{2}{*}{$\begin{array}{c}\text { Dstnce } \\
\text { (m) }\end{array}$} & \multicolumn{2}{|c|}{ Transport } & \multirow[b]{2}{*}{ CC (IDR) } & \multirow{2}{*}{$\begin{array}{l}\text { Fixed cost } \\
\text { (IDR) }\end{array}$} & \multirow{2}{*}{$\begin{array}{l}\text { Total cost } \\
\text { (IDR) }\end{array}$} \\
\hline & & & $\begin{array}{c}\text { Rate } \\
\text { (IDR/ton) }\end{array}$ & 4 & & & \\
\hline Cg_3 & $\mathrm{C}$ & & $2,832.73$ & & & & \\
\hline Cg_3 & Baru & 1,10 & $2,347.53$ & & 14,1 & & 27, \\
\hline Cg_3 & Kos & $2,029.28$ & $3,052.80$ & 17,9 & 47.49 & & 43, \\
\hline Cg_3 & Sdrh & & $2,744.25$ & $27,943,872.79$ & 35,5 & & $71,722,336.01$ \\
\hline Crgn & Crgn & 0 & 0 & 0 & $28,936,900.77$ & $20,295,600.00$ & $49,232,500.77$ \\
\hline
\end{tabular}

Total cost : $226,405,826.38$

$($ Cg_3 = Center of Gravity Cluster 3 Iteration 2, Crym = Ciroyom, Kos = Kosambi, Crgn = Caringin Sdrh = Sederhana) 
longer able to be grouped (cluster 3 , this process fails).

If we analyze all cluster results as shown in Table 11 where the whole clustering processes has been done, it turns out that the optimal clustering process is cluster 2 , in which the logistics costs are the most minimum costs compared with other clusters. This means that the location of the warehouse and the ideal number is listed in cluster 2, as follows:

- 1 warehouse for Ciroyom, Baru, and Kosambi. The location of the warehouse is located at the coordinates $(8.77 ; 8: 50)$, namely on $\mathrm{Jl}$. Kebonjati

- 1 warehouse for Sederhana, which is in itself

- 1 warehouse for Caringin, which is in itself

- The total cost of logistics for that condition is IDR 213,369,501.24. That logistics cost is he most minimum if being compared with other state conditions.

\section{CONCLUSION}

The result of calculation shows that the ideal location of warehouses of 5 major markets in Bandung municipality (Sederhana, Ciroyom, Baru, Kosambi, and Caringin) are 1 warehouse at Kebon Jati to supply Ciroyom, Baru, and Kosambi Markets, 1 warehouse at Sederhana to supply Sederhana Markets, and at Caringin to supply Caringin Markets. As a comparison, the initial logistics cost incurred for Cimindi Warehouse accounts for IDR 258,401,701.24 per year, while the logistics cost in cluster 2 spends only IDR 213,369,501.24 (from Table 8), so the savings obtained is IDR 45,032,203.00 per year, or approximately IDR 125,000 per day. That results if being compared to the current real situation, the location of Dolog warehouse in Cimindi has actual capacity 27,500 ton (source: Dolog, West Java) whereas the result of forecast demand for the next 3 years counts the capacity 33,392.64 ton. This means there is a problem of insufficient warehouse capacity as 5,892.64 tons per year if Dolog still uses Cimindi Warehouse to date. Thus, there are two alternative solutions that can be used as follows by using the old warehouse and enhancing the shortage storage capacity by opening additional warehouse (at $\pm 6,000$ tons) or opening new warehouses in ideal locations.

\section{REFERENCES}

Ballou, R.H., 2003. Business Logistics Management Planning and Control, $5^{\text {th }}$ Edition, Englewood Cliffs, New Jersey: Prentice-Hall Inc.

BPS Jabar, 2008. Laporan Hasil Survei Volume Penjualan Eceran Beras di Kodya Bandung, Bandung.

Bulog, 1994. Pedoman Pembiayaan DOLOG, Jakarta.

Mulyati, E., 2011. Penentuan Strategi Pendistribusian Air Mineral dalam Kemasan, Prosiding Kopertis Wilayah IV, 4-9.

Murti, S.J., Aisyati, A, dan Suhardi, B., 2004. Penentuan Jumlah dan Lokasi Gudang yang Optimal dengan Menggunakan Metode Cluster, Jurnal Performa, 3 (1), 1-8.

Suthamphong, A., 2012. Identifying an Optimal Facility Location for Factory: A Review of Project Report, Journal of Supply Chain Management, Assumption University of Thailand, 4, 82-98.

Thai, V.V. and Grewal, D., 2005. Selecting the Location of Distribution Centre in Logistics Operations: A Conceptual Framework and Case Study, Asia Pacific Journal of Marketing and Logistics, 17 (3). 